\title{
EFEKTIVITAS BAHAN AJAR YANG DIKEMBANGKAN DENGAN TAKSONOMI SOLO SUPERITEM UNTUK PROSES PENALARAN MATEMATIS SISWA
}

\author{
Siska Firmasari \\ Program Studi Pendidikan Matematika FKIP UNSWAGATI \\ J1. Perjuangan No.01 Kota Cirebon, siska.f1105@gmail.com
}

\begin{abstract}
ABSTRAK
Penelitian ini dilakukan untuk melihat perbedaan proses penalaran matematis siswa kelas $\mathrm{X}$ di SMA Negeri 2 Kota Cirebon menggunakan bahan ajar yang dikembangkan dengan Taksonomi SOLO Superitem dibandingkan dengan bahan ajar biasa. Metode penelitian yang digunakan adalah penelitian pengembangan yaitu pengembangan bahan ajar pembelajaran matematika dengan Taksonomi SOLO Superitem. Pengembangan bahan ajar ini difokuskan pada penyusunan bahan ajar. Instrumen yang digunakan yaitu instrumen tes kemampuan penalaran matematis. Dari hasil penelitian diperoleh bahwa kemampuan penalaran matematis kelas uji coba bahan ajar melebihi kriteria ketercapaian rata-rata kelas dan ketuntasan individual melebihi $75 \%$ sehingga dapat disimpulkan bahan ajar yang dikembangkan dengan Taksonomi SOLO Superitem efektif untuk proses penalaran matematis siswa kelas X SMA materi dimensi tiga.
\end{abstract}

Kata Kunci : Bahan Ajar, Taksonomi SOLO Superitem, penalaran matematis

\begin{abstract}
This study was conducted to see the differences in mathematical logic process tenth grade students at SMAN 2 Cirebon use learning materials developed by the SOLO Taxonomy Superitem compared with regular learning materials. The method used in this research is the development of research is the development of learning materials learning mathematics with SOLO Taxonomy Superitem . Material development is focused on the preparation of learning materials. The instruments used are mathematical logic ability test instrument. The result showed that mathematical logic ability the class of testing- materials exceed the average achievement criteria and completeness class individually exceeded $75 \%$ so that it can be concluded that the learning materials developed by the SOLO Taxonomy Superitem effective for mathematical logic process tenth grade students in three-dimensional subject.
\end{abstract}

Keywords: Learning Materials, SOLO Taxonomy Superitem , mathematical logic

Pendahuluan

Berdasarkan hasil evaluasi

keterlaksanaan KTSP Tahun 2009 yang

diselenggarakan oleh Direktorat

Pembinaan SMA, ditemukan bahwa

masih banyak guru yang belum mampu

mengembangkan bahan ajar secara

mandiri (Dit. Pembinaan SMA, 2010).
Selain itu, guru lebih banyak mengandalkan buku paket atau bahan ajar yang disusun oleh guru lain karena kurangnya kesadaran akan pentingnya menyusun bahan ajar yang sesuai dengan kebutuhan siswa, manfaat bahan ajar dalam penyiapan perangkat pembelajaran dan pelaksanaan pembelajaran, serta 
kurangnya pemahaman guru akan mekanisme dan teknis menyusun bahan ajar yang benar.

Dari hasil diskusi dengan para pengajar di salah satu SMA Negeri favorit di Kota Cirebon, kesulitan utama yang ditemui selama proses pembelajaran adalah bahan ajar yang digunakan masih belum mampu mengurangi kesulitan siswa dalam memahami materi yang disampaikan. Hasil diskusi tersebut kemudian berkembang menjadi materi matematika yang memiliki tingkat kesulitan yang tinggi bagi para pengajar untuk disampaikan dan siswa untuk dipelajari dan dipahami. Diperoleh data tentang hasil UTS, UAS, Try Out yang dilakukan pihak sekolah selama lima tahun terakhir, ternyata nilai terendah terdapat pada mata pelajaran dimensi tiga. Maka dapat disimpulkan bahwa bahan ajar yang umumnya digunakan berupa textbook atau buku teks yang pemaparan materi dan contoh soal penggambaran bentuk dan pola dimensi tiganya masih membingungkan siswa.

Mempertimbangkan keadaan yang telah dibahas sebelumnya, maka peneliti memerlukan adanya sebuah bahan ajar yang disesuaikan dengan kebutuhan siswa untuk menyelesaikan permasalahan siswa menerapkan konsep-konsep pembelajaran matematika yang saling terkait. Bahan ajar yang dimaksud menggunakan penjelasan konsep kepada siswa yang tidak langsung pada konsep atau proses yang kompleks, tetapi dimulai dari konsep dan proses yang sederhana. Berdasarkan alasan tersebut, peneliti menyusun bahan ajar menggunakan struktur yang dinamakan taksonomi atau tahapan SOLO (Structure of the Observed Learning Outcome). Bahan ajar ini merupakan alternatif bahan ajar dalam pembelajaran matematika yang dimulai dari penguasaan konsep yang sederhana meningkat pada yang lebih kompleks

Taksonomi SOLO yang diterapkan dalam penyusunan bahan ajar dilengkapi dengan soal-soal latihan bentuk superitem. Bahan ajar dengan menggunakan soal-soal latihan bentuk superitem adalah bahan ajar yang dimulai dari soal-soal yang sederhana meningkat pada yang lebih kompleks dengan memperhatikan tahapan SOLO siswa (Sumarmo, 1993).

Tujuan dari penelitian ini adalah memperoleh bahan ajar menggunakan taksonomi SOLO Superitem materi jarak dalam ruang dimensi tiga kelas $\mathrm{X}$ yang efektif.

Pengembangan Bahan Ajar dan Model Yang Digunakan

1. Bahan Ajar

Kemampuan guru dalam mengembangkan bahan ajar terkait 
dengan kompetensi pedagogik dan kompetensi profesional seperti yang tercantum dalam lampiran Permendiknas Nomor 16 Tahun 2007 tentang Standar Kualifikasi Akademik dan Kompetensi Guru bagian B, Guru sebagai pendidik profesional diharapkan memiliki kemampuan mengembangkan bahan ajar sesuai dengan mekanisme yang ada dengan memperhatikan karakteristik dan lingkungan sosial peserta didik.

Bahan ajar adalah segala bentuk bahan berupa seperangkat materi yang disusun secara sistematis yang digunakan untuk membantu guru/instruktur dalam melaksanakan kegiatan pembelajaran dan memungkinkan siswa untuk belajar (Dit. Pembinaan SMA, 2010).

Bahan ajar berfungsi sebagai berikut:

1. Pedoman bagi Guru yang akan mengarahkan semua aktivitasnya dalam proses pembelajaran, sekaligus merupakan substansi kompetensi yang seharusnya diajarkan/dilatihkan kepada siswanya.

2. Pedoman bagi siswa yang akan mengarahkan semua aktivitasnya dalam proses pembelajaran, sekaligus merupakan substansi kompetensi yang seharusnya dipelajari/dikuasainya.

3. Alat evaluasi pencapaian/penguasaan hasil pembelajaran.
4. Membantu guru dalam kegiatan belajar mengajar

5. Membantu siswa dalam proses belajar

6. Sebagai perlengkapan pembelajaran untuk mencapai tujuan pelajaran.

Untuk menciptakan lingkungan /suasana belajar yang kondusif

\section{Pengembangan Bahan Ajar}

Plomp (dalam Tahmir, 2006) menyatakan secara singkat bahwa mengkarakteristikkan desain bidang pendidikan sebagai metode yang didalamnya orang bekerja secara sistematik menuju ke pemecahan dari masalah yang dibuat.

Model pengembangan bahan ajar yang digunakan adalah Model Plomp yang telah dimodifikasi terdiri dari fase investigasi awal (prelimenary investigation), fase desain (design), fase realisasi/konstruksi

(realization/construction), dan fase tes, evaluasi dan revisi (test, evaluation and revision). Fase yang terakhir yaitu fase implementasi (implementation) tidak digunakan dikarenakan keterbatasan waktu dan kemampuan peneliti.

\section{Kemampuan Penalaran Matematis}

Kemampuan penalaran setiap individu adalah berjenjang berdasarkan tingkat perkembangan individu tersebut. Perkembangan intelektual setiap individu disesuaikan dengan usia anak. Hal ini 
seperti dikemukakan oleh Piaget (dalam Hudojo, 1988) bahwa setiap individu mengalami tingkat-tingkat perkembangan intelektual, yaitu: tingkat berpikir sensorimotor, pra-operasional, operasi konkrit, dan operasi formal. Kemampuan Penalaran matematis adalah kemampuan menyajikan suatu obyek matematika (masalah, pernyataan, solusi, model, dan lainnya) ke dalam berbagai notasi yang meliputi:

a) Simbolik/abstrak formal (bentuk aljabar, formula), dalam memanipulasi, menginterpretasi, dan beroperasi dengan simbol.

b) Visual/ikonik, dalam menginterpretasi, membuat, dan beroperasi pada grafik dan/atau gambar.

c) Numerik/tabular, dalam menerapkan prosedur, memahami dan menerapkan proses, dan mengintepretasi tabel. (Sumarmo, 2003:15)

Penalaran matematis siswa dapat berkembang dengan seringnya siswa mengerjakan latihan-latihan soal melibatkan masalah dan pengetahuan prosedural mereka. Jadi, siswa akan terbiasa terlatih mengaitkan konsepkonsep yang ada dari setiap materi matematika yang pernah mereka terima sebelumnya dengan materi baru yang mereka pelajari.

\section{Taksonomi SOLO Superitem}

Menurut Biggs dan Collis (dalam Lian, Yew, dan Idris, 2010) bahwa setiap tahap kognitif terdapat struktur respons yang sama dan makin meningkat dari yang sederhana sampai yang abstrak. Berdasarkan kualitas respon anak, struktur hasil belajar taksonomi SOLO pada anak diklasifikasikan pada lima tahapan. Kelima tahap tersebut adalah prastruktural (menolak memberikan respon atau menjawab tanpa dasar yang logis), unistruktural (menarik kesimpulan berdasarkan satu hubungan data atau informasi secara konkret), multistruktural (menarik kesimpulan berdasarkan dua atau lebih hubungan data atau informasi, namun masih terpisah), relasional (menarik kesimpulan berdasarkan dua atau lebih hubungan data atau informasi secara terintegrasi), dan abstrak (berpikir deduktif dan dapat menyusun prinsip umum atau hipotesis berdasarkan informasi yang diberikan).

Sumarmo (2003) memberikan alternatif pembelajaran yang dimulai dari yang sederhana meningkat pada yang lebih kompleks. Pembelajaran tersebut menggunakan soal-soal bentuk superitem sebagai tugas. Pembelajaran menggunakan tugas bentuk superitem adalah pembelajaran yang dimulai dari tugas yang sederhana meningkat pada 
yang lebih kompleks dengan memperhatikan tahap SOLO siswa.

\section{Metode Penelitian}

Penelitian ini merupakan penelitian pengembangan yaitu pengembangan bahan ajar pembelajaran matematika dengan Taksonomi SOLO Superitem Pengembangan bahan ajar ini difokuskan pada penyusunan bahan ajar dan tes hasil belajar kemampuan penalaran matematis.

Bahan ajar yang dikembangkan dalam pengembangan ini adalah bahan ajar materi jarak dalam ruang dimensi tiga mengacu pada model pengembangan pendidikan umum dari Plomp yang dimodifikasi. Modifikasi yang dilakukan adalah dengan adanya penyederhanaan model dari lima fase menjadi empat fase tanpa menyertakan fase implementasi setelah fase tes, evaluasi, dan revisi selesai dilakukan. Hal ini dilakukan karena keterbatasan waktu dan kemampuan peneliti.

Teknik analisis data menggunakan analisis instrumen tes kemampuan penalaran matematis dan analisis efektivitas pembelajaran.

\section{Populasi dan Sampel}

Populasi dalam penelitian ini adalah seluruh siswa kelas X SMAN 2 Cirebon. Teknik pengambilan sample yang digunakan adalah simple random sampling yaitu suatu teknik pengambilan anggota sampel dari populasi yang dilakukan secara acak tanpa memperhatikan strata yang ada dalam populasi tersebut. Pada penelitian ini diambil sampel pertimbangan yaitu siswa kelas X.11 sebagai kelas uji coba bahan ajar dan X.9 sebagai kelas kontrol.

\section{Hasil dan Pembahasan}

(a) Fase Investigasi Awal (Preliminary Investigation)

Hasil pengamatan pembelajaran yang berlangsung di SMA 2 Cirebon menunjukkan bahwa pembelajaran masih terpusat pada guru (teacher centered), pembelajaran tidak didukung dengan bahan ajar yang memadai karena bahan ajar yang digunakan sering menyulitkan siswa untuk memahami materi yang sedang dipelajari, nilai rata-rata ketuntasan yang diperoleh siswa pada mata pelajaran matematika terutama materi dimensi tiga masih rendah.

(b) Fase Desain (Design)

Berdasarkan kajian teori pada tahap investigasi awal, pada tahap ini dirancang bahan ajar dengan Taksonomi SOLO Superitem materi jarak dalam ruang dimensi tiga. Bahan ajar yang dirancang yaitu buku siswa yang juga memuat 
lembar kerja siswa sedangkan instrument tes yang dirancang yaitu TKPM (Tes Kemampuan Penalaran Matematis).

(c) Fase Realisasi/Konstruksi

Pada fase ini disusun bahan ajar yang sesuai dengan pengembangan bahan ajar metode Taksonomi SOLO Superitem materi jarak dalam ruang dimensi tiga. Bahan ajar yang dihasilkan dalam fase ini selanjutnya disebut draf I.

(d) Fase Tes, Evaluasi, dan Revisi

\section{$\underline{\text { Hasil Uji Efektivitas }}$}

Data nilai TKPM yang diperoleh digunakan untuk mengetahui tingkat keberhasilan penggunaan bahan ajar hasil pengembangan. Tingkat keberhasilannya diukur melalui uji statistika, yaitu: uji ketuntasan (uji ketercapaian rata-rata kelas), dan uji banding, tetapi sebelumnya dilakukan uji normalitas dan uji homogenitas.

Uji ketercapaian rata-rata menggunakan uji One Simple t-Test dan uji proporsi dua pihak menggunakan uji z dapat disimpulkan bahwa rata-rata kemampuan penalaran matematis siswa kelas uji coba bahan ajar tidak sama dengan 70 , dengan nilai mean $=73,83$ maka nilai rata-rata ketuntasan belajar kelas uji coba bahan ajar lebih dari 70 , sedangkan ketuntasan klasikal tidak sama dengan $75 \%$, atau bila dilihat dari jumlah siswa yang mencapai ketuntasan sebanyak 27 siswa maka disimpulkan bahwa ketuntasan klasikal melebihi $75 \%$.

Uji banding dengan menggunakan rumus Independen Sample t-test dapat disimpulkan bahwa rata-rata kemampuan penalaran matematis kelas yang memperoleh bahan ajar manggunakan Taksonomi SOLO Superitem tidak sama dengan kelas yang memperoleh bahan ajar buku paket sekolah, untuk melihat rata-rata yang lebih baik dari kedua kelas, dapat dilihat dari nilai mean nya ternyata nilai rata-rata kelas uji coba $(73,83)$ lebih baik dari rata-rata kelas biasa $(67,50)$. Hal ini menunjukkan secara nyata keberhasilan pengembangan bahan ajar dengan Taksonomi SOLO Superitem. Keberhasilan ini disebabkan karena pengembangan bahan ajar dengan Taksonomi SOLO Superitem berhasil menunjukkan proses kemampuan penalaran matematis siswa yang berjalan baik dan positip serta kecakapan yang dimiliki siswa juga menuju arah positip.

Hal lain yang menjadi penyebab keberhasilan pengembangan bahan ajar dengan Taksonomi SOLO Superitem karena bahan ajar yang berupa buku siswa dikembangkan dengan penyusunan yang bertahap baik dari segi materi maupun penyampaian contoh-contoh soal serta latihan yang diberikan dari tahap sederhana sampai tahap yang kompleks, 
sehingga kemampuan penalaran matematis siswa bisa terbangun dengan baik.

\section{Kesimpulan}

Berdasarkan tujuan penelitian dan hasil maka dapat disimpulkan bahwa bahan ajar menggunakan Taksonomi SOLO Superitem efektif.

\section{Saran}

Berdasarkan simpulan yang dikemukakan di atas, maka peneliti menyarankan:

1. Dalam pembelajaran materi jarak dalam ruang dimensi tiga disarankan agar menggunakan bahan ajar yang dikembangkan dengan Taksonomi SOLO Superitem, dengan tetap memperhatikan penyusunan bahan ajar yang sesuai dengan materi dan disajikan secara menarik sehingga siswa tidak mengalami kejenuhan dalam belajar.

2. Dalam penyusunan bahan ajar agar diperhatikan tingkat kemampuan siswa pada lingkungan sekolah yang bersangkutan sehingga bahan ajar yang disusun sesuai sehingga dapat dimaksimalkan penggunaannya.

\section{Pustaka}

Arjanggi, R. dan Suprihatin, T. 2010. Metode Pembelajaran Tutor Teman Sebaya Meningkatkan Hasil Belajar Berdasar RegulasiDiri. Semarang : Unissula. Jurnal
Makara, Sosial Humaniora, Vol. 14, No. 2, Desember 2010:91-97.

Dirawat. 1993. Sistem Pembinaan Profesional dan Cara Belajar Siswa Aktif. Jakarta: PT. Gramedia

Direktorat Pembinaan SMA. 2010. Juknis Pengembangan Bahan Ajar SMA.

Herianto, D., Siahaan, P., dan Kusnendar, J. 2010. Efektivitas Model Pembelajaran Tutor Sebaya terhadap Hasil Belajar Siswa dalam Belajar Microsoft Excel di Kelas VIII SMP Dua Mei Banjaran. Jurnal UPI Bandung

Hudojo, H. 1988. Mengajar Belajar Matematika. Jakarta : Dirjen DIKTI

Lian, L. H., Yew, W.T., dan Idris, N. 2010. Superitem Test: An Alternative Assessment Tool To Assess : Students' Algebraic Solving Ability. Journal International : Malaysia

Rudhito,M,A. 2008. Geometri Dengan Wingeom, Panduan Dan Ide Belajar Geometri Dengan Komputer. Yogyakarta : FKIP Universitas Sanata Dharma

Sumarmo,U 1993. Profil Struktur Hasil Belajar Matematika Siswa SMA Berdasarkan Taksonomi SOLO. 
Laporan Hasil Penelitian FPMIPA

IKIP Bandung

Sumarmo, U. 2003. Daya dan Disposisi Matematik: Apa, Mengapa dan Bagaimana Dikembangkan pada Siswa Sekolah Dasar dan
Menengah. Makalah disajikan pada Seminar Sehari di Jurusan Matematika ITB, Oktober 2003.

Uno, H. 2011. Motivasi Belajar dan Alat Pengukurnya. Bandung: Rosda Karya 